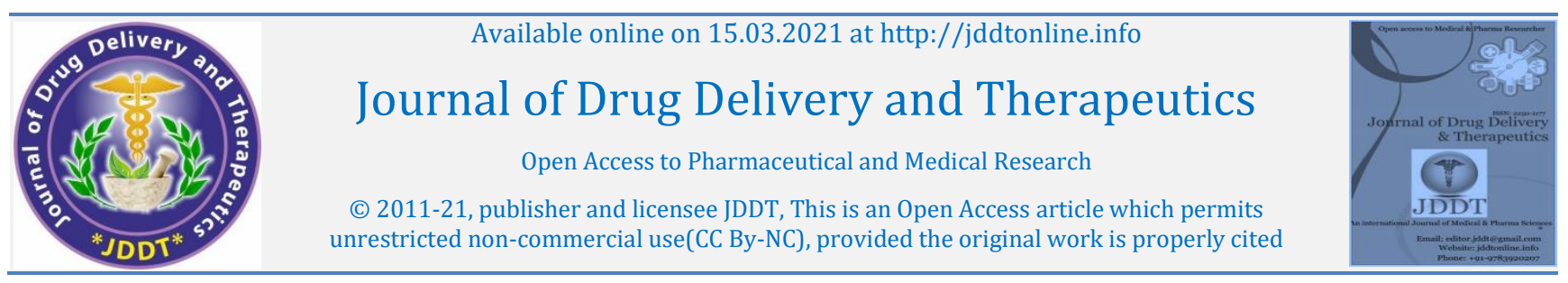

(C) 2011-21, publisher and licensee JDDT, This is an Open Access article which permits

Open Access Full Text Article

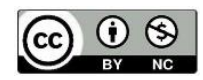

Review Article

\title{
Understanding the concept of Purgation (Ishal) in Unani Medicine: A Review
}

\author{
Hina Kouser V1, Fatima Khan ${ }^{1}$, Ayesha Tehseen ${ }^{1}$ Mohd Nayab*2 (D) Abdul Nasir Ansari $^{3}$ \\ ${ }^{1}$ PG Scholar, Dept. of Ilaj bit Tadbeer, NIUM, Bengaluru, India \\ ${ }^{2}$ Assistant Professor, Dept. of Ilaj bit Tadbeer, NIUM, Bengaluru, India \\ ${ }^{3}$ Professor \& HoD, Dept. of Ilaj bit Tadbeer, NIUM, Bengaluru, India
}

\section{Article Info:}

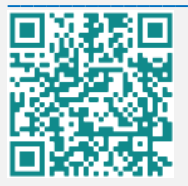

\section{Article History:}

Received 07 Jan 2021:

Review Completed 16 Feb 2021

Accepted 26 Feb 2021;

Available online 15 March 2021

\section{Cite this article as:}

Kouser VH, Khan F, Tehseen A, Nayab M, Ansari AN, Understanding the concept of Purgation (Ishal) in Unani Medicine: A Review, Journal of Drug Delivery and Therapeutics. 2021;11(2):241-246 DOI: http://dx.doi.org/10.22270/jddt.v11i2.4584

\section{*Address for Correspondence:}

Dr. Mohd Nayab, Department of Ilaj bit Tadbeer, National Institute of Unani Medicine, Bengaluru, India - 560091. ORCID ID: 0000-0003-2077-9659

\begin{abstract}
The theory of humours (akhlat) is one of the fundamental pillars of the Unani System of Medicine (USM). The concept of health and disease depends on the quality (kaifiyat) and quantity (kammiyat) of humour (khilt). Health (sehat) lasts when humours remain in equilibrium and the main determinant of health is the balance in six essential factors (asbab$e$-sittah zarooriya). These factors are highly modifiable and deviation in any of them leads to disequilibrium in humours either qualitatively or quantitatively which ultimately manifests in the form of the disease. Elimination (istifragh) of these morbid humours from the body becomes mandatory to treat the diseases or to restore health. One of the effective methods of elimination is purgation (ishal). It is a method by which morbid humours from the body are eliminated through the anal route. Before the elimination of any pathological humour especially in chronic diseases, it is mandatory to make the humour easily eliminable. This process of making the pathological humour eliminable is known as concoction (nuzj). The process of concoction is a regular and continuous process of the tabiyat (mediatrix naturae) of the body. In case of a minor deviation in humour, tabiyat itself eliminates it from the body after concoction. When the causative pathological humours are in abundance or grossly deviated from normalcy, tabiyat needs help from outside the body. This help of tabiyat can be done with some humour specific drugs which are known as concoctive medicines (munzij advia). Once, the humours become eliminable, the process of evacuation can be started. Classical Unani literature and published papers were explored to find the rationale of purgation therapy. Purgation is found to be advisable in the treatment of many chronic diseases. Tabiyat is the ultimate healer in the body and purgation helps it to overcome the diseases.
\end{abstract}

Keywords: Istifragh; Munzij; Nuzj; Akhlat; Humours; Concoction

\section{Introduction:}

The theory of four humours is the backbone and landmark of Unani medicine. The four cardinal humours are blood (dam), phlegm (balgham), yellow bile (safra) and black bile (sauda). These four humours are different in colour, appearance, composition, physical properties and proportions. A healthy individual will have a balanced mixture of these humours. The humours are produced in the body after digestion and metabolism of dietary contents. Equilibrium in the humours is maintained by the balance in production and elimination of these humours. Qualitative or quantitative disequilibrium in these humours leads to disease condition ${ }^{1,2}$. Six essential factors (asbab-e-sittah zarooriya) viz. atmospheric air (hawa-e-muheet), food and drink (makool wa mashroob), body movements and repose (harkat wa sukoon badni), mental activity and repose (harkat wa sukoon nafsani), sleep and wakefulness (naum wa yaqza) and retention and evacuation (ehtibas wa istifragh), are also considered the determinant of good health. These factors are highly modifiable and deviation in any of these factors is likely to cause disequilibrium in humours. Proper evacuation of vitiated humours is the prerequisite of humoral equilibrium or in other words maintenance and restoration of health 2,3 , 4 . The treatment policy in Unani medicine is described under three headings i.e. regimenal therapy (ilaj bit tadbeer) and dietotherapy, (taghziya), pharmacotherapy (ilaj bid dawa), and surgery (ilaj bil yad) ${ }^{3}, 5$. The employment of regimenal therapy is one of the best measures of health promotion in Unani medicine. It is one of the most popular treatment techniques since antiquity practiced by ancient Unani physicians. Regimenal therapies are the procedures through which we modulate the patient's lifestyle, dietary habits and habitat and practice several other therapeutic regimens for the treatment of various diseases ${ }^{6}$. Avicenna (Ibne Sina) has described 36 regimens including Leeching (Irsale Alaq), Venesection (Fasd), Purgation (Ishal), Emesis (Qai), Diuresis (Idrar), etc. These regimens are meant for the evacuation and elimination of morbid humours from the body. As soon as these redundant humours are removed from the body, 
normal health is restored. Purgation is one of the basic and important regimens for treating several chronic diseases and is intended for the elimination of morbid humours from the body responsible for the disease condition 7, 8. Before the elimination of morbid humours from the body, it is mandatory to make them eliminable from the sites of lodgment. This process is known as concoction (nuzj) and the drugs used in this process are known as concoctive (munzij advia). Concoctive are classified according to the specific vitiated humour involved in the disease process as phlegmatic concoctive (mundij-e-balgham), yellow bile concoctive (munzij-e-safra), and black bile concoctive (mundij-e-sauda). Concoction and elimination are primarily done by tabiyat. When tabiyat is weak or morbid humour is in abundance such that it cannot be removed from the body it needs help from outside in the form of concoctive drugs. These drugs enhance the process of recovery and healing in the injured and inflamed tissues by their anti-inflammatory, analgesic, antioxidant and antiseptic properties ${ }^{8-11}$.

\section{Methodology:}

The data for the present paper was extracted from peerreviewed journal articles. The Unani literature has been taken from classical Unani treatises such as Al Qanoon Fit Tibb by Ibn Sina, Kulliyat-i-Qanoon by Ibn Sina, Kulliyate Nafeesi by Alama Burhanuddin Nafees, Kaamilus Sanaah by Ali Ibn Abbas Majoosi, Kitabul Murshid by Zakariya Razi, Kitabul Kulliyat by Ibn Rushd.

\section{Results and discussion:}

Ilaj bit Tadbeer is one of the basic treatment modalities in Unani medicine. This paper discusses one of the methods of removal of pathological humours from the body. The removal of morbid humours from the body is known as istifragh (elimination) which allows the biological systems to return to homeostasis, to rejuvenate, to facilitate the therapeutic pharmacological agents to act effectively 6 . Elimination can be achieved through various procedures such as cupping therapy (hijama), venesection (fasd), emesis (qai), purgation (ishal), etc. Classical Unani literature showed that the process of elimination acts as a preventive as well as the curative method of treatment if performed within the mentioned guidelines ${ }^{8}$.

\section{General Principles of Elimination:}

For carrying out purgation the following five principles should be kept in consideration 8,11-15.

1. Only causative pathological matter should be eliminated from the body.

2. Elimination should be in the direction of outflow; thus, griping should be treated with purgation and nausea with emesis.

3. Elimination should be through an appropriate organ or in the direction of the drifted matter.

4. The time for elimination should be decided according to the presence or absence of a concoction of morbid matter.

5. The quantity of matter should be estimated from; the amount of matter in the body, the strength of the patient, and the chances of complications.

\section{Conditions for Elimination:}

Certain conditions should always be followed during the elimination process $8,11-13,15$

\section{Plethora:}

- If there is a plethora in the body, elimination is indicated

- If the body is in a state of depletion then elimination is contraindicated.

\section{Strength:}

- Elimination is indicated when all the three primary faculties are strong.

- Elimination is contraindicated in case of weakness of any of the three primary faculties.

\section{Temperament:}

- Elimination is contraindicated in patients having hotdry (har-yabis) and cold-moist (barid-ratab) temperaments.

\section{Physique:}

- Moderately built patients are suitable for elimination.

- It is contraindicated in excessively lean and obese patients.

5. Age:

- Elimination is indicated in young and middle-aged persons.

- It is contraindicated in children, old aged persons, pregnant and menstruating women.

\section{Season:}

- Spring (rabee) and autumn (khareef) seasons are favourable for elimination.

- It should be avoided in extreme hot and cold weather.

7. Local climate:

- The residents of moderately hot southern countries and moderately cold northern countries are considered suitable for elimination.

- Purgation is contraindicated in the residents of extremely hot and cold countries.

8. Habits:

- People who are habitual of the elimination process are more suitable.

- It should usually be avoided in unaccustomed persons of elimination.

\section{Occupation:}

- Elimination is contraindicated in all physically active and hard workers as it produces fatigue.

\section{Existing diseases:}

- Elimination specifically through purgation is contraindicated in the patients suffering from diarrhoea, intestinal ulcers etc.

\section{Importance of Concoction (nuzj):}

Humours in the ideal healthy body have a certain consistency and optimum physical characteristics. These humours are used by the organs in ideal consistency and the same is needed for their elimination from the body. Excessively dense (ghaleez), and viscous (lazeej) forms of morbid humours are not only difficult to eliminate from the body but also for use by the organs. Optimum consistency 
for elimination is achieved by the process of concoction that is not only necessary for evacuation of morbid humours from the body but also important to make it usable by the organs inside the body 10-11. In normal circumstances, tabiyat with the help of innate heat (hararat-e-ghareezia) acts as a concoction. It is a routine process of the body in the presence of temperamental normalcy but if temperament is disturbed then proper concoction cannot take place. In such a condition, tabiyat needs to be stimulated from outside the body to complete the process and for this reason, specific medicines are required, the drugs which are used for concoction, are called concoctive drugs (munzij advia) ${ }^{16}$.

\section{Conditions for concoction:}

1. Chronic diseases (duration $>40$ days).

2. It is sometimes recommended in acute diseases where the duration is more than seven days.

3. The concoction is not mandatory for diseases lasting less than seven days

4. The concoction is mandatory before purgation in phlegmatic (balghami) and black bilious (saudawi) diseases. However, it is optional in yellow bilious (safrawi) diseases and not required in sanguineous (damwi) diseases.

\begin{tabular}{|l|l|l|}
\hline \multicolumn{2}{|c|}{ Duration of concoction 10, 17 } \\
\hline S. No. & Name of humour involved & Number of days \\
\hline 1. & Safra-e-Khalis & 3 days \\
\hline 2. & Safra-e-Ghair Khalis & 5 days \\
\hline 3. & Balgham-e-Raqeeq & 5 days \\
\hline 4. & Balgham-e-Ghaleez & 12 days \\
\hline 5. & Sauda-e-Khalis & $15-40$ days \\
\hline
\end{tabular}

\section{Signs of concoction:}

To examine the signs of concoction is important to induce purgation. Signs of concoction are examined by urine, pulse, sputum, etc.

The signs of concoction in urine can be detected by a change in colour, viscosity, and precipitate or specific gravity. The pulse becomes soft (layyin) towards the end of the process of concoction, if it is hard (sulb) at the beginning and vice versa 10,18 . Changes in the consistency of the sputum are indicative of concoction in the diseases of lungs and thorax ${ }^{18}$. As soon as the signs of concoction become visible, appropriate purgatives should be started 10,18 .

\section{Purgation (Ishal):}

Purgation is a method of elimination of morbid humours from the body through the anal route. The drugs, used for purgation, are known as purgative (mushilat). The eliminated matter through purgation contains contents not only from the intestines and neighbouring areas but also from the lungs in the form of phlegm, from spleen in the form of black bile, from blood in the form of water. Purgation increases the frequency of stool in several ways, like increasing the watery content of the intestines, increasing the peristaltic movement or lubrication of the intestines.

\section{Classification of purgatives 19}

\section{1) Mild Purgatives (Mamooli Mushil):}

Mild purgatives result in the passage of one or two episodes of loose stool, includes the following;

\begin{tabular}{|l|l|l|l|}
\hline Unani Name & Botanical Name & Unani Name & Botanical Name \\
\hline Elva & Aloe vera & Revand & Rheum palmatum \\
\hline Irsa & Iris ensata & Senna & Cassia senna \\
\hline Kamela & Mallotus phillipinesis & Sooranjan & Colchicum leutium \\
\hline
\end{tabular}

\section{2) Strong Purgatives (Qawi Mushil):}

Strong purgatives result in the passage of frequent loose stools that may be watery. It includes:

\begin{tabular}{|l|l|l|l|}
\hline Unani Name & Botanical Name & Unani Name & Botanical Name \\
\hline Beikh Jalapa & Ipomoea purga & Rasaut & Berberis aristata \\
\hline Habbul Neel & Ipomoea hederacea & Saqmoonia & Convolvulus scamony \\
\hline Jamalgota & Croton tiglium & Shehm Hanzal & Citrullus colocynthis \\
\hline Kherbaq Siyah & Helliborus niger & Roghan Jamalgota & Croton tiglium oil \\
\hline
\end{tabular}




\section{Purgatives related to Humour/matter 19}

a. Phlegm Purgatives:

These drugs work to discharge phlegm through the intestines due to their specific structure. Several drugs may be used, each having a particular proportion of chemical constituents, thereby allowing for different actions as required.

\begin{tabular}{|l|l|l|l|}
\hline Unani Name & Botanical Name & Unani Name & Botanical Name \\
\hline Afteemoon & Cuscuta reflexa & Ersa & Iris ensata \\
\hline Anzroot & Astragallus sarcacola & Ghareequn & Polyporus officinalis \\
\hline Baobarang & Artemisia vulgaris & Habbunneel & Ipomoea hederacea \\
\hline Bisfaij & Polypodium vulgare & Jalapa & Ipomoea purge \\
\hline Kanghi & Abulitone indicum & Qust & Sassurea lappa \\
\hline Muqil & Commiphora mukul & Roghan Bedanjir & Ricinus communis \\
\hline Senna & Cassia senna & Shehem Hanzal & Citrullus colocynthesis \\
\hline Shoneez & Nigella sativa & Sibr zard & Aloe vera \\
\hline Thohar & Euphorbia nerifolia & Turbud & Ipomoea turpenthum \\
\hline Usthukhuddus & Lavandula stoechas & Zaravand & Aristolochia longa \\
\hline
\end{tabular}

\section{b. Yellow bile purgatives:}

These drugs act on yellow bile and pass it through the intestines.

\begin{tabular}{|l|l|l|l|}
\hline Unani Name & Botanical Name & Unani Name & Botanical Name \\
\hline Aaloobukhara & Prunus domestica & Senna & Cassia senna \\
\hline Ersa & Iris ensata & Shahtra & Fumaria officinalis \\
\hline Gule Banafsha & Viola odorata & Sheerkhisht & Fraxinus ornus \\
\hline Gul surkh & Rosa damascena & Sibr zard & Aloe vera \\
\hline Gulqand, Haleela Zard & Terminelia chebula & Tamar Hindi & Tamarindus indica \\
\hline Saqmoonia & Convolvulus scamony & Turunjabeen & Tamarix indica \\
\hline
\end{tabular}

\section{c. Black bile purgatives:}

These drugs act on black bile and pass it through the intestines

\begin{tabular}{|l|l|l|l|}
\hline Unani Name & Botanical Name & Unani Name & Botanical Name \\
\hline Afteemoon & Cuscuta reflexa & Jamalgota & Croton tiglium \\
\hline Baobarang & Artemisia vulgaris & Kherbaq Siyah & Helliborus niger \\
\hline Bisfaij & Polypodium vulgare & Senna & Cassia senna \\
\hline Habbul Neel & Ipomoea hederacea & Turbud & Ipomoea turpenthum \\
\hline Haleela Siyah & Terminelia chebula & Ushq & Dorcus ammonicum \\
\hline
\end{tabular}

\section{Aims and Objectives of Purgation 10,12}

- To eliminate the causative pathological humours from the body.

- To bring down the temperature in cases of hyperpyrexia.

- To eliminate excess fluids from the body. e.g., Ascitic fluid.

- To eliminate excess bile, phlegm and black bile.

- To bring down the blood pressure in cases of hypertension.

- To prevent attacks of certain diseases prophylactically.

\section{Preferable time for purgation $8,12,13,16$}

- Purgation should be avoided in extreme hot and cold climates.

- Favourable weather for purgation is spring and autumn season.

\section{General Rules for purgation $8,12,13,15$}

The following rules should be taken into account before starting purgation:

- A small quantity of food should be taken before inducing purgation. 
- The meal should consist of a variety of food because the stomach and the intestines tend to expel the heterogeneous type of food.

- If the intestines are ready to purge, no preparation is needed and if it is necessary, then only simple steps such as exercise, massage and baths are sufficient.

- In the case of inflammatory bowel diseases, purging is painful, so it should be avoided.

- Before purgation, the offending humour should be prepared through concoction.

- The body should be prepared in advance whenever a strong purgative is given.

- Baths at specific intervals are effective in liquifying the vitiated matter before purgation.

- In the case of scybala (hardened masses of faeces), purgatives should not be given before removing the scybala with an enema or some emollient.

- When a purgative fails to act even after a sufficient duration of time, no further action should be taken unless the patient develops any unexpected symptom.

- Before inducing the purgation, good sleep is recommended

- $\quad$ Before purgation, the patient should be asked to take a sitz bath in lukewarm water as it relaxes the anus and surrounding structures which helps the morbid matter to pass easily.

- People with bilious stomach or on diet or fast should eat bread soaked in wine before taking the purgatives.

\section{Rules to be followed during and after \\ purgation $10,13,15$}

- Physical activities should be avoided after taking purgatives for their proper absorption.

- If the purgatives taste bad, the patients should be advised to chew Aqarqarha.

- In case of vomiting due to bad smell or taste of purgatives, the patient should be given Sirka, Pudina, Karafs, Gule Khurasani with Arq Gulab.

- Purgatives, in the form of decoction, should be taken lukewarm. If in the form of a pill or powder then it should be taken with lukewarm water.

- Purgatives should be given on empty stomach. Pomegranate juice or barley water should be given before purgatives to people with hot temperament.

- $\quad$ Fatty food should be given before a strong purgative such as hellebore to a person having the dry temperament.

- A bath should be avoided immediately after taking purgatives.

- It is better to sleep after taking strong purgatives as it helps in increasing the effect of purgation.

- In the case of weak purgatives, the person should not be allowed to sleep.

- Non-palatable pills can be coated with honey or some other palatable flavours.

- People with cold temperament should take a decoction of Haloon (water-cress) with olive oil after purgation.
- People with hot temperament should take Luab-eAsapgool with cold water or Banafsha oil (oil of violets) with Nabat Safaid (white sugar) after taking purgatives.

- People with moderate temperament should take Tukhm-e-Katan.

- Massage or oil rub also aids in purgation.

- Barley water should be used if a person develops fever after purgation.

- If the effect of purgatives is delayed then Maul Asl should be used

\section{Signs of Successful Purgation 12}

- No restlessness or agitation after purgation.

- The discharge of a new form of matter, after the clearance of offending material, is a sign of successful elimination.

- An overwhelming desire for sleep.

\section{Signs of Excessive Purgation 8, 12, 13}

- Increased thirst is an indication to arrest purgation.

- The nature of stools indicates the need for cessation of purgation.

- Expulsion of blood following purgation is a sign of danger.

- Other signs of excessive purgation are dry tongue, cold skin and loss of skin turgidity.

- $\quad$ Passage of shreds from the lining membranes of bowels and dark foul-smelling matter in the faeces are indicative of cessation of purgative therapy.

\section{Treatment of Excessive Purgation 12,13}

Excessive purgation generally results from:

- The weakness of the vessels

- Widening of the passages

- Irritation of vascular orifices

- The temperamental or other allied abnormalities

- Excessive purgation is stopped by tightly bandaging the arms and legs starting from the armpits and groins.

- If a patient develops colic due to excessive purgation then suitable antidote should be given and sweating should be induced with a hot water bath or vapour bath.

- The body should be massaged and astringents should be administered orally after sufficient sweating. To keep the body warm, limbs should be massaged, or hands and feet should be immersed in hot water. It is worth preventing cold exposure.

- To provide warmth, fire cupping should be done over the joints and between the shoulder blades.

- Purgation can also be arrested with emesis induced by warm water

- The essence of sandalwood, camphor or some fragrant should be presented for smelling. 
- To alleviate excessive purgation, roasted barley or powdered poppy (papaver somniferum) seeds are also helpful.

- The diet should contain astringents such as the ice-cold juice of sour grapes.

- Excessive purgation from poisonous herbs such as Mazerioon (Maseru) and shibran (Spurge laurel) is treated with curd.

- Bora-e-Armani (Armenian Bore) and pomegranate juice are administered if there is a risk of bowel ulceration.

- If a person develops a fever after purgation, barley water should be given or venesection should be done.

\section{Conclusion:}

Diseases due to vitiated humours in the form of lifestyle disorders are now a challenging problem for the medical fraternity. By taking into account the concept of istifragh and ehtebas, these disorders can be prevented. Purgatives play a very important role in the treatment of various chronic ailments; it is high time to prove their efficacy on modern scientific parameters so that a vast section of the population can be benefited from them.

\section{Conflict of Interest}

Authors declare no conflict of interest

\section{References:}

1. Israili AH., Humoural Theory of Unani Tibb, Indian Journal of History of Science, 1981; 16(1):95-99.

2. Majoosi, Kaamilus Sanaa (Urdu translation by Kantoori GH), Vol 1st. New Delhi: Idarae Kitabus Shifa; 2010.

3. Saleem S, Saleem S, Mujeeb K, Khan MI, Sherani FS, Implication of Asbab-e-Sitta Zarooriyah in Prevention of Lifestyle Diseases: A Review, International Journal of Advanced Research, 2015; 3(10):407-12.

4. Rahman A, Ali SJ, Aslam M, Rashid B., Asbabe Sitta Zarooriya (Six Essentials of Life): A Review, Indo American Journal of Pharmaceutical Sciences, 2014; 1(6):402-506.
5. Anjum R., Regimental Therapy (Ilaj-bil-Tadbir) An Ancient Method for Promotion of Health \& Treatment of Different Diseases, International Conference of Public Health: Issues, challenges, opputunities, prevention, awareness, Public Health, 2016:346-348.

6. Nasir A., Fatma G., Ali W., Ahmad MA., Role of Ilaj-bit-Tadbeer (Regimental Therapy) as Non-Medical Therapy in Unani System of Medicine, EJPMR, 2018; 5(2):213-18.

7. Taher MA., Nayeem MA., Ahammed MM., Chowdhury SI., Ilaj-bilTadbeer (Regimental Therapy): A Review, International Journal of Medical and Health Research, 2017; 3(10):54-56.

8. Sina I, Kulliyate Qanoon. (Urdu translation By Kabeeruddin), New Delhi: Idarae Kitabus Shifa; 2015.

9. Lone AH, Ahmad T, Anwar M, Sofi G, Imam H, Habib S, Perception of health promotion in Unani herbal medicine, Journal of Herbal Medicine, 2012; 2(1):1-5.

10. Hamdani K, Usoole Tib, New Delhi: National Council for promotion of Urdu language; 1998.

11. Nafees AB, Tarjuma wa Shahrae Kulliyate Nafeesi (Urdu translation By Kabeeruddin), New Delhi: Idarae Kitabus Shifa; YNM.

12. Ahmed Z, Alam A, Ghufran, Rabee K, Qamri MA, Hasan N, Regimenal Therapy in Unani Medicine with Focus on Purgatives-Avicenna's Approach, Int J Pharmacognosy, 2014; 1(7):409-14.

13. Shah MH, The General Principles of Avicenna's Canon of Medicine, New Delhi: Idarae Kitabus Shifa; 2007.

14. Ilahi A, Mannan A, Alam M, Ali A, Norms for Qai (Vomiting) and Is'hal (purgation): The Traditional Graeco-Arabic approaches, JISHIM. 2013-2014.

15. Sina I, Al Qanoon Fit Tib (Urdu translation By Kantoori GH), Vol 1st. New Delhi: Idarae Kitabus Shifa; YNM.

16. Ibn Rushd M, Kitabul Kulliyat (Translated by CCRUM), New Delhi: CCRUM; 1987.

17. Shamsi Y, Khan AA, Alam T, Jabeen A, Management of Cancer with Munzij and Mus'hil Therapy: A Regimen of Ilaj bit Tadbeer (Regimenal Therapy) in Unani System of Medicine, Int J Cur Res Rev, 2016; 6(5):4-9.

18. Razi Z, Kitabul Murshid (Urdu translation By Nadvi MR), New Delhi: Tarqi Urdu Bureau; 2000.

19. Kabir H, Unani Materia Medica and the Concept of Purgation: A Safe Regimental Therapy (Ilaj Bit-Tadbeer), Tibb Institute, 2010: $1-15$. 